\title{
Relational Key Account Management: Building Key Account Management effectiveness through Structural Reformations and Relationship Management Skills
}

\author{
By \\ Spiros Gounaris, PhD* \\ Professor of Marketing \\ University of Strathclyde Business School, \\ Department of Marketing \\ Sir William Duncan Building \\ 130 Rottenrow \\ Glasgow G4 0GE \\ Tel: +44 1415483233 \\ E-mail: spiros.gounaris@strath.ac.uk \\ Nektarios Tzempelikos, $\mathrm{PhD}$ \\ Senior Lecturer in Marketing \\ Anglia Ruskin University \\ Lord Ashcroft International Business School \\ East Road \\ CB1 1PT, Cambridge \\ UK \\ Room: Lab322 \\ Tel: +448451962664 \\ E-mail: nektarios.tzempelikos@anglia.ac.uk
}

* Lead author for correspondence 


\section{Biography}

Spiros Gounaris is Professor of marketing at the department of marketing of the University of Strathclyde Business School. He is also director of $\mathrm{PhD}$ studies at the University of Strathclyde Business School. His research interests include services marketing, internal marketing, digital marketing, key account management and business-to-business marketing. His work has been published in many American and European prestigious journals

Nektarios Tzempelikos is Senior Lecturer in marketing in the Lord Ashcroft International Business School, Anglia Ruskin University. His research interests include key account management, relationship marketing and customer value in the business-to-business context. His research has been published in Journal of Business \& Industrial Marketing, Journal of Business-to-Business Marketing, Journal of Strategic Marketing, The IMP Journal and Journal of Relationship Marketing. 


\section{Research highlights}

- The adoption of a relational perspective in KAM will result in necessary, structural reformation while allowing for specific relational skills to develop

- The building of a structure that supports KAM and the relational capabilities jointly enhance the relationship quality between the supplier and the customer.

- Besides the financial impact a KAM program has, through better relationship quality the supplier achieves significant non-financial benefits

- The benefits of KAM remain strong independently of resources available to the supplier, 


\begin{abstract}
Literature has widely recognized the importance of Key Account Management (KAM) in building long-term customer relationships. Although KAM grounds significantly on the relationship marketing theory, most empirical studies focus on the financial impact a KAM program can produce. Hence, only normative work can advise practitioners on the implications from adopting a relational approach in managing their business with customers who can help the supplier realise a broader set of strategic objectives. Drawing from 304 cases of different suppliers, this manuscript seeks to start filling this gap in the literature and offer empirical evidence regarding the structural and relational implications from a KAM program. In summary, the findings suggest that adopting a relational perspective through the development of key account management orientation (KAMO) will result in certain, necessary, structural reformation while allowing for specific relational skills to develop. Consequently, supplier's performance also improves. Moreover, this chain of effects remains strong independently of resources available to the supplier, suggesting that KAM can be a significant basis for developing a competitive advantage irrespectively of the supplier's size.
\end{abstract}

Keywords: key account management, organisational structure, relationship quality, relationship marketing, empirical 


\section{Relational Key Account Management: Building Key Account Management effectiveness through Structural Reformations and Relationship Management Skills}

\section{Introduction}

Key Account Management (KAM) has received significant attention by both academics and practitioners in recent years (Guesalaga \& Johnston, 2010). KAM is the systematic process of managing B2B relationships that are of strategic importance to the supplier (Millman \& Wilson, 1995; Homburg, Workman, \& Jensen, 2002). KAM involves performing additional activities aiming to tailor the supplier's offering to meet the individual, often unique, needs of the key account (KA). Less important customers do not receive this kind of treatment (Workman, Homburg, \& Jensen, 2003; Salojärvi, Sainio, \& Tarkiainen, 2010). Hence KAM is more than concentrating the sale effort on customers generating large sums of sales revenue (Spencer, 1999); KAM represents a proactive development towards a customer-focused organisation (Gosselin \& Bauwen, 2006) with important organisational implications (Salojärvi et al., 2010).

KAM is the practice of relationship marketing in business markets (e.g. Ivens \& Pardo, 2007; Richards \& Jones, 2009; Salojärvi et al., 2010; Zupancic, 2008). As such, KAM moves away from short-term, transactional exchanges and focuses on more long-term, strategic and collaborative relationships (Ryals \& Humphries, 2007). Surprisingly enough though, prior research sustains a transaction, exchange-focused view, which remains highly concentrated on the sales / profit potential of the KA (Wengler, Ehret, \& Saab, 2006). Consequently past investigation has also failed to incorporate the supplier's relational capabilities in explaining the outcomes of a KAM program. Finally, because KAM requires summoning significant resources to meet the needs of individual KA through customisation, it remains unclear whether KAM programs can potential be equally effective for smaller suppliers as it can be for larger ones.

With these gaps in the extant literature in mind, the present study seeks to empirically examine the effect of key account management orientation (KAMO) on the supplier's organisational structure, relational capabilities and performance from a relational vantage. In addition, drawing on the resource based view of the firm, this study seeks to explore how the size of the supplier as manifested by the 
supplier's span of control can moderate the impact of the KAM program on the supplier's relational, financial and non-financial outcomes.

Answering these research questions will allow making a significant contribution on three fronts. The first contribution comes from exploring the nomological significance of KAMO adoption as an antecedent of the structural adjustments and relational capabilities that affect the quality of the relationship between the two companies and eventually the supplier's performance. The second contribution comes from the investigation of the joined, interrelated, effect specific structural choices and relational capabilities have on the quality of the relationship between the supplier and the KA and, consequently, on the supplier's performance. Finally, by examining the moderation effect that span of control has on the outcome of the KAM effort, this study seeks to make a contribution by answering whether KAM is equally suitable for suppliers with varying access to resources.

Next, we first present the theoretical background underpinning this investigation, followed by the conceptual framework and research hypotheses. Next, we present the methodology before we proceed with data analysis and hypotheses testing. Finally, we present the discussion of the findings, the limitations and the directions for future research this manuscript opens.

\section{Literature Review}

\subsection{Relationship Marketing and Key Account Management}

"National Account Management" was used in the eighties to describe the supplier's effort to deal with accounts operating nationwide generating large sales volumes and revenue (e.g. Shapiro \& Moriarty, 1984). At that time, achieving sales objectives was a crucial strategic priority mainly driven by the growth rates witnessed in many different sectors (Shapiro \& Wyman, 1981). However, during the years that followed many suppliers saw growth rates relaxing while a smaller number of "national accounts", as the result of consolidation, commanded a larger proportion of the market. This produced an imbalance of power between suppliers and customers with the latter growing stronger. As a result, customers could impose harder deals squeezing the supplier's profit margin. Heightened competition among suppliers and competitive turbulence eroded further suppliers' margins. The initial reaction was cost restructuring and an attempt to improve transactional efficiency (Weilbaker \& Weeks, 1997), 
which however could not be a sustainable strategy in the long run, especially as business was increasingly becoming globalised (Montgomery \& Yip, 2000).

With profitability endangered, other objectives, such as reference value or know how development became important strategic priorities as a means for the suppliers to differentiate from competition and compensate for relatively higher costs and prices (cf. Boles, Johnston \& Gardner, 1999; Millman \& Wilson, 1999). Consequently, suppliers' attention starts shifting from facilitating present and future transactions with "National Accounts" at a low cost to strengthening the relationship between the two companies, understanding the account's needs better and developing the necessary know-how to cater for these needs; the concept of relationship marketing introduced in the nineties has geared this paradigm shift for many suppliers (Grönroos, 1994).

The extant literature reports on the importance of adopting a relationship marketing approach in managing customer relationships (Morgan \& Hunt, 1994). In a broader perspective, the implementation of a relationship marketing strategy seeks to identify the customers who are more likely to respond positively and maintain a long-term relationship with the company if the supplier can satisfy their needs and wants (Parvatiyar \& Sheth, 2000). In other words, a relationship marketing strategy is not relevant to all customers; a relational strategy targets only these customers who are likely to commit themselves in a long-term relation with the supplier.

Relationship marketing is especially important in the business-to-business (B2B) context where customers tend to be few and powerful and buyer-seller relationships are characterized by complexity, interdependence and a long-term orientation (Heide \& John, 1992; Anderson \& Narus, 1990). Within this context, suppliers have to identify existing and/or potential customers whose approaches to purchasing warrants a long-term relation and commitment to the supplier who will provide them with a superior solution and meet their purchasing needs and criteria (Pressey, Tzokas, \& Winklhofer, 2007). Moreover, suppliers have also to consider the cost associated with the organisational restructuring necessary to facilitate a relationship marketing strategy as well as the cost of adapting their operational procedures, product assortment and features and business practices to match the customer's individual needs (Homburg, Workman, \& Jensen, 2000). Therefore, the deployment of a relational strategy is limited to a relatively smaller number of existing or potential customers; the "Key Accounts": these customers with whom the supplier identifies a significant strategic fit 
(McDonald, Millman, \& Rogers, 1997). Suppliers can then deploy a relationship marketing strategy aiming to better understand the specific requirements of such customers and satisfy them. The implementation and management of this relational strategy lies at the heart of the "Key Account Management" notion, the evolution of NAM within the relationship marketing paradigm (Abratt \& Kelly, 2002; McDonald et al. 1997). Hence, within this paradigm, we define KAM as "the management of the supplier's relational strategy, manifesting the willingness of the supplier to assume the effort (and cost) to customise its offering to meet the unique requirements of customers with whom (the supplier) sees a strategic fit ("Key Accounts") so that (the supplier) can realise significant strategic objectives that outweigh the sacrifices of customisation".

Following from this definition, suppliers engage in KAM because of the anticipated long term benefits from the collaboration with KAs. Suppliers can usually benefit from higher revenues (Workman et al., 2003), know-how development (Pels, 1992; Ojasalo, 2001), reference power (McDonald et al., 1997; Ojasalo, 2001) or entering new markets and exploring emerging market opportunities (Boles et al., 1999). Customers also benefit from a KAM initiative through customized offerings, closer cooperation, and faster response (Ryals \& Humphries, 2007). However, the ability to co-create value in the relationship cannot be taken for granted (Ryals \& Humphries, 2007). Trust between the two parties and commitment in the relationship usually precede the ability of the supplier and the customer to co-create value through their relationship (Millman \& Wilson, 1995). In turn, the anticipated value from the relationship influences the process and the criteria through which KAs are identified. While in the past sales revenue was the yardstick by which suppliers identified important national accounts, under the relationship marketing paradigm and the practice of KAM, suppliers use a variety of criteria such as status or potential for developing know-how to identify their KAs (e.g. Boles et al., 1999; Pels, 1992; McDonald et al., 1997). Hence, the practice of KAM is not limited to larger customers; smaller accounts can also be identified as "key" and qualified to enter the suppliers KAM program as long as the supplier perceives them to serve and facilitate the accomplishment of his own strategic objectives (Millman \& Wilson, 1995).

From the previous discussion on relationship marketing it becomes evident that NAM and its driving principles have become obsolete and a new paradigm has emerged as the framework underlying the management of the relationship between the supplier and the customer. 


\subsection{Key Account Management Orientation: A Paradigm Shift.}

Over the past years, many studies have produced empirical evidence of the benefits from a close buyer-seller relationship and customer centricity (e.g. Morgan \& Hunt, 1994; Cannon \& Perreault, 1999). Relationship success largely depends on the ability of the management to adopt and implement a customer relationship orientation (Day, 2000), which establishes a "collective mind" in the organisation according to which the relationships with the customers represent assets (Jayachandran, Sharma, Kaufman \& Raman, 2005). Customer orientation is pervasive influencing all interactions with customers before, during and after the sale (Day, 2000) driving thus the choice of means (processes) to develop and sustain customer relationships (Jayachandran et al. 2005; Salojärvi et al., 2010). Nevertheless, customer relationship orientation tends to concentrate on "customer segments". In KAM, the focus is on the individual account for whom resources are often reallocated from other non-key accounts (Homburg et al., 2002). Hence, a different mind-set is necessary to facilitate the transition from traditional sales to KAM (Davies \& Ryals, 2009).

To capture this paradigm shift, Gounaris and Tzempelikos (2013) suggest the notion of “Key Account Management Orientation" (KAMO), the adoption of which manifests the supplier's readiness to move from the transaction-based NAM to the relationship-based KAM. As such, KAMO reflects the supplier's willingness and ability to respond effectively to the KA's needs integrating the cultural and behavioural perspective of the Market Orientation (MO) notion (Narver \& Slater, 1990, Jaworski \& Kohli, 1993, Hult, Ketchen, \& Slater, 2005) in the business -to- business context. Yet, KAMO is conceptually different from MO because of the strategic importance that certain customers (KAs) have for the supplier. While MO treats the customer base in its entirety a KAM program relies on the distinction between customers of strategic importance and other, average, customers (Homburg et al., 2002; Workman et al., 2003). Hence KAMO captures the supplier's readiness to invest further resources to ensure the supplier's ability to fulfil the needs and expectations of the KAs (Gounaris \& Tzempelikos, 2013). As such, KAMO represents a set of values reflecting the supplier's attitude towards the management of the relationship with KAs. These include (1) a priority to meet the needs of the KA before anything else (Shapiro \& Moriarty, 1984), (2) a top management committed to become involved and ensure the company, as a whole, meets the needs of the KA (Millman \& Wilson, 1999; Pardo, 1999) and (3) an interdepartmental coordination to respond to the needs of the KA (Homburg et al., 2002). KAMO also engulfs a set of values that demonstrate the supplier's actual 
behaviour and KAM practices. These capture (1) the supplier's ability to customization (Homburg et al., 2002; Zupancic, 2008; Jones, Richards, Halstead, \& Fu, 2009), (2) the involvement of the topmanagement in managing the business relations with the KA (Homburg et al., 2002) and (3) the interfunctional support the other departments offer to KAM function (Workman et al., 2003; Kahn \& Mentzer, 1998). Developing both sets of values evidences the adoption of KAMO, which in turn represents the first and necessary step towards the transition towards a relationship based practice of managing the business relation with a KA.

\subsection{Research Framework and Hypotheses}

Figure 1 presents the research model of the study. As Figure 1 shows, this study explores the effect of KAMO adoption on the supplier's organisational structure and relational capabilities. Through structural reformation and relational capabilities development, the suppliers who adopt KAMO improve the quality of the relation with the KA and eventually achieve a number of performance outcomes. In the following sections we develop specific research hypotheses on the grounds of the extant literature.

\section{INSERT FIGURE 1 AROUND HERE}

\section{KAM and Implications for the Supplier's Organisational Structure}

As customer power over suppliers increases and relationships with suppliers become more complex, suppliers need to become more collaborative and flexible in their business with their KAs (Davies \& Ryals, 2009; Homburg et al., 2000). Hence, organisational structure becomes an important concern as structure can impede organisational learning and cross-departmental collaboration reducing thus the supplier's ability to promptly and effectively react to KA needs (Achrol, 1991). Thus, to facilitate the customer centricity a KAM program promotes, organisational structure need to adapt in a manner that will improve the supplier's agility and readiness to respond to such needs and requirements (Salojärvi et al., 2010; Homburg et al., 2000).

Different facets of the organisational structure may be affected by this redesign effort. For instance, the degree of departmentalisation, the division of labour or the hierarch of authority are some characteristics of the structure that will most probably need reviewing. However, of the many different characteristics, two are key for ensuring the success of a KAM program: organisational 
formalisation and organisational centralisation (Walker \& Ruekert, 1987; Jaworski \& Kohli, 1993; Homburg et al., 2000).

Organisational formalisation captures the degree to which a set of predefined roles, procedures, and authority in decision making (Jaworski \& Kohli, 1993; Hall, Haas, \& Johnson, 1967) drives the behaviour of the organisation and how the organisation responds in a myriad of situations ranging from routine tasks to entirely new projects. Organisational centralisation reflects the span of decision-making in the organisation and the degree of empowerment managers in relatively lower hierarchical levels (Jaworski \& Kohli, 1993; Aiken \& Hage, 1968). Higher levels of formalisation and centralisation have been associated with detrimental bureaucracy (Hurley \& Hult, 1998) that diminishes the supplier's ability to surpass existing business models and codes of conduct when this is necessary to meet emerging unique requirements of strategically important customers. Under such situations, customers usually expect to become more involved and to have an opinion in the development of the solution the supplier offers, which in turn require a rather agile organisation from the supplier's part (Vargo \& Lusch, 2008). Hence, as the supplier adopts KAMO, the organisational structure will also have to gain in agility to accommodate and facilitate this new relational ecology and the shift from transactional KAM practices. This eventually results in less formalised and less centralised structures. On this ground we examine the following hypotheses:

\footnotetext{
Hla: As the degree of KAMO adoption increases the degree of organisational centralisation will decrease.

H1b: As the degree of KAMO adoption increases the degree of organisational formalisation will decrease.
}

\section{KAM and Relational Capabilities}

The investigation of the impact on the company's competitiveness from the effective and efficient use of scarce resources roots back in the mid eighties and the resource based view (RBV) theory (Wernerfelt, 1984). According to RBV firms develop a competitive advantage when they possess resources or capabilities that are valuable, unique, imperfectly imitable, and non-substitutable (Barney, 1991). Given the importance of KAs, KAM relationships can be viewed as an important asset of the supplier (Ivens \& Pardo, 2007). In this respect, the RBV becomes particularly relevant allowing for a deeper understanding of the factors that improve KAM effectiveness. Following from 
the KAM framework discussed earlier in the manuscript, building and maintaining long-term relationships with key accounts helps suppliers to achieve their strategic objectives and, consequently, a competitive advantage. The adoption of KAMO should therefore affect the supplier's ability to access and use certain resources that will allow the supplier to derive a competitive advantage.

Of the many different resources, skills and capabilities represent "a special type of resource, specifically an organisationally embedded non-transferable firm-specific resource whose purpose is to improve the productivity of the other resources possessed by the firm" (Makadok 2001, p.389). Within the relational KAM ecology, one such skill is the supplier's ability to develop business bonds with the customer. Achieving this requires the development of certain relational capabilities (Srivastava, Shervani, \& Fahey, 1998; Dyer \& Singh, 1998; Theoharakis, Sajtos, \& Hooley, 2009). Relational capabilities reflect the supplier's skill to manage customer relationship effectively so that eventually the two companies can develop mutual bonds (Srivastava et al., 1998; Dyer \& Singh, 1998). The rationale behind the introduction of relational capabilities is that value is not only created inside the firm, but also outside (Theoharakis et al., 2009). Information sharing and conflict resolution are two key capabilities that influence the supplier's customer bonding ability (cf. Ryals \& Humphries, 2007; Richards \& Jones, 2009; Millman \& Wilson, 1999).

Information sharing captures the degree to which the two companies exchange useful information of confidential, such as cost structure, nature (Heide \& John, 1992), while conflict resolution reflects the degree to which the two parties resolve disagreements productively, while avoiding tensions and future ill-will (Anderson \& Narus, 1990). As the supplier becomes more inclined to understand the needs of the KA the supplier becomes equally willing to establish open channels of information and share mutually beneficial intelligence (Millman \& Wilson, 1999; Ojasalo, 2001). Moreover, as the supplier adopts KAMO, the top-management becomes more involved with the KAM effort, facilitating thus the management of potential conflicts with KAs (Mohr \& Spekman, 1994; Millman \& Wilson, 1999; Homburg et al., 2002). On these grounds we suggest the following hypotheses:

H2a: KAMO adoption directly increases the supplier's willingness to share information with the Key Account 
H2b: KAMO adoption directly enhances the supplier's ability to resolve conflicts with the Key Account.

KAMO adoption also affects the supplier's relational capabilities indirectly through the organisational structure. Sharing valuable information and resolving conflicts effectively and swiftly requires the management of the supplier to promptly respond to matters arising between the two companies (Mohr \& Spekman, 1994). To meet this requirement the supplier has to allow for decision making to take place on the spot and without any bureaucratic interference (Ngo \& O'Cass, 2009). Furthermore, reducing formality allows managers to tailor internal procedures to accommodate unique, unpredictable customer requirements (Vorhies, Harker, \& Rao, 1999). Having the structure that allows management to take such actions triggers the conditions necessary for information sharing and effective conflict resolution between the two companies (Heimeriks \& Duysters, 2007). On this ground we examine the next hypotheses:

H3a: KAMO adoption improves information sharing capabilities indirectly through lower levels of centralisation and formalisation of the organisational structure.

H3b: KAMO adoption affects conflict resolution capabilities indirectly through lower levels of centralisation and formalisation of the organisational structure.

\section{Improving Relationship Quality and performance outcomes}

Building long-term KAM relationships requires the supplier to seek to strengthen its competitive position in the eyes of the KA, attract more business from the same account and acquire new business from other customers with whom a strategic fit can also be possible (McDonald et al., 1997). As far as the former is concerned, a good indicator of the supplier's potential to sustain and/or enhance the level of business the KA offers to the supplier is the quality of the relationship between the two companies. Relationship quality represents the assessment of the strength of the buyer-seller relationship (Crosby, Evans, \& Cowles, 1990). Late work on the notion of relationship quality would seem to come to a consensus that customer satisfaction, trust and commitment to the supplier are the components upon which the notion of relationship quality grounds (e.g. Dorsch, Swanson, \& Kelley, 1998; Garbarino \& Johnson, 1999; Crosby et al., 1990).

The supplier's organisational structure clearly affects the quality of the relation between the two companies. For instance, suppliers often adopt a geographical organization of the sales function. 
As a result they frequently set significant geographical distance between the supplier's top management and the manager(s) responsible to interact with the KA. In such situations, decisionmaking is delayed, especially when the approval by the senior management is also required (Woodburn \& McDonald, 2011). More customer-centric organisational structures resolve such issues and provide the basis for strengthening the quality of the relationship with the KA (Homburg et al., 2000).

To improve the degree of customer centricity of the organisational structure, suppliers must empower cross-functional teams to make decisions and solve the account's problems (Jones, Dixon, Chonko, \& Cannon, 2005). Likewise increased levels of organisational flexibility allow the supplier to improve the degree of responsiveness to the unique/emerging needs of the KA (Woodburn \& McDonald, 2011). Moreover, a customer centric organization allows the supplier and the KA to improve the openness of the communication channels, enhance the effectiveness of the conflict resolution mechanisms and eventually produce a more positive and cooperative climate (Mohr \& Spekman, 1994; Morgan \& Hunt, 1994), which in turn builds up the level of relationship quality between the two companies (Leuthesser, 1997; Crosby et al., 1990; Anderson \& Narus, 1990). On these grounds, we investigate the following hypotheses:

H4a: The less centralised and formalised the supplier's organisational structure, the higher the level of relational quality between the supplier and the $K A$.

H4b: The stronger the supplier's relational capabilities (information sharing and conflict resolution) the higher the level of relational quality between the supplier and the $K A$

Prior research provides substantial evidence that links the quality of the relationship between the supplier and the KA with the supplier's financial performance (e.g. Jones et al., 2009). This comes as little surprise since a substantial proportion of the supplier's business comes from KAs, which in turn is reflected directly on the supplier's overall organisational performance (Workman et al., 2003). Specifically, if satisfaction, trust and commitment to the supplier increase, the amount of business the customer gives to the supplier also increases (Jones et al., 2009; Huntley, 2006), while operational cost decreases as a result of economies of scale in serving the KA and lower vulnerability to competitors' initiatives (such as price cuts) which the supplier does not have to necessarily meet (Reichheld, 1996). On these grounds, we investigate the following research hypothesis: 


\section{H5: Higher levels of relationship quality will positively affect the financial performance of}

the supplier.

Moreover, the extant literature suggests that establishing a high level of relationship quality could produce a wide range of positive outcomes for the supplier, which in turn strengthens the supplier's competitive position in the market (Ivens \& Pardo, 2007). One such outcome is the gaining of reference value. Reference value describes the supplier's opportunity to increase the image and status of the company in the market through the relationship with certain KAs and thus gain new or more business from other customers (McDonald et al., 1997; Ojasalo, 2001). A second positive outcome for the supplier is know-how development. In providing the KA with the right solution the supplier has frequently to customise, to a more or less extent, either the features of the product or some other aspect of the value chain or both (Zupancic, 2008). As a result the supplier develops skills and know-how in production and service (Pels, 1992; Ojasalo, 2001). An additional benefit is the improvement of internal communication (Boles et al., 1999). This is explained by the increased pressure for coordination and facilitation of communication among firm's departments in order to response to KA needs. Suppliers also benefit from building a strong relationship quality with their KAs because planning and control becomes easier, which in turn allows the supplier to gain in operational efficiency (Caspedes, 1993). On these grounds we investigate the following hypothesis:

H6: Higher levels of relationship quality will positively affect the non-financial performance of the supplier.

\section{The Moderation Effect of Strategic Resources Limitation / Affluence}

According to the extant literature, a relational mind-set in KAM allows the supplier to benefit from KAM regardless of the amount of resources the supplier commands (Woodburn \& McDonald, 2011). On the other hand, following from the "resource-based view" of the firm (Wernerfelt, 1984), the possession of resources that are valuable to the customer and hard for the competitors to imitate helps a supplier to derive a competitive advantage. One such strategic resource within the ecology of relational KAM is the span of control and the number of KAs for which each KA Manager is responsible.

Larger suppliers for instance, compared to relatively smaller ones, in addition to securing access to superior technology, they can also recruit more KA managers, who also are more 
experienced and of higher calibre (Piercy, 2006). Consequently, such suppliers, compared to relatively smaller ones, are more likely to accrue more benefits from a KAM project because they can reduce the span of control and assign less KAs per KA Manager (Narver \& Slater, 1990; Homburg et al., 2002). As a result, suppliers with a relatively lower span of control, compared to suppliers with a greater span of control, will be better-off in managing the relationship with their KAs because the KA managers will have more time to deal with the KA's problems and to coordinate better the supplier's response to the unique and emerging needs and wants of the KA. On these grounds, we investigate the next hypothesis:

\section{H7: Span of control moderates the link between KAM performance outcomes and their antecedents.}

\section{Method}

\subsection{Sample, Response Rate and Sampling Unit}

Data were collected by means of a structured questionnaire. Over a twelve months period we collected 304 usable questionnaires from a randomly selected sample of 800 companies (response rate $38 \%$ ) covering a variety of different sectors including fast moving consuming goods, chemicals, pharmaceuticals, computer and electronics, banks and insurances, telecommunications, metals, furniture, medical equipment and professional services in Greece.

To generate the sample we first contacted ICAP Hellas, a leading consulting company in Greece publishing the most comprehensive catalogue of Greek companies across all economic sectors. Using the electronic edition of the latest catalogue we contacted through email all companies ( $\mathrm{n}=7385$ at the year of investigation) with an annual sales income more than $\$ 6.5 \mathrm{~m}$ (£4.1m) asking the Marketing or Sales Manager two simple questions: If the company practices KAM and who is/are responsible for managing the company's KAs.

To allow variance in responses, we were careful not to define or otherwise clarify the meaning of "Key Account Management". Regardless of the prevailing perspective in KAM (transactional or relational), many companies employ the term "Key Account Manager" for sales representatives calling on "Key Accounts" (Wengler et al., 2006). Hence responses come from companies who could 
possibly be assigned anywhere between the two extremes of a theoretical continuum which the transactional and the relational views on KAM respectively anchor.

From the 7385 companies 2402 replied. These 2402 companies are the population from which we randomly selected a third to contact. To collect the data we called each of the 800 companies in the sample. After we explained the objectives and the purely academic nature of the study we asked for their participation and arranged a date for a personal interview since the length of the questionnaire and the complex nature of many questions make personal interviewing the most appropriate data collection method (Hair, Anderson, Tatham, \& Black, 1998).

The appointment was with higher-level managers (positions include 'National Accounts Manager', 'Key Accounts Manager', 'Marketing Manager' and 'Sales Manager', depending on each firm's organisational structure). Although adopting the key informant technique may impede the generalizability of the findings (Phillips, 1981), using appropriate measurement scales can provide reliable and valid data (John \& Reve, 1982). Hence, given the study objectives and the need to collect information from higher level managers with an overall understanding of the organisation as a whole (Homburg et al., 2002) we proceeded with the Key Informant approach.

\subsection{Measures and Questionnaire Development}

All measures in the study are adopted or adapted from previous pertinent empirical research except that of non-financial outcomes. Moreover, the questionnaire was pre-tested with three marketing academics and ten practitioners from the population under investigation to increase content validity and clarity of the measures. Considering their comments, some items were eliminated while others revised to improve precision and clarity. All items were measured using a seven point scale (detailed scales items are reported in the Appendix).

To assess the degree of KAMO adoption we employ the measure presented by Gounaris and Tzempelikos (2013), while organisational structure, centralisation and formalisation were measured using the scales suggested by Jaworski and Kohli (1993). Relationship quality is operationalised based on satisfaction, trust and commitment (Cannon \& Perreault, 1999, Doney \& Cannon, 1997 and Morgan \& Hunt, 1994), while information sharing (Heide \& John, 1992) and conflict resolution (Anderson \& Narus, 1990) capture the supplier's relational capabilities. The assessment of financial performance relied on the self-evaluation of organizational sales, profitability, market share and ROI. 
Non-financial outcomes are measured using multi-item scales capturing reference value, know-how development, processes' efficiency and intra-firm communication. Finally, to assess span of control we asked the participants to indicate the number, on average, of KAs for which a single KA Manager is responsible to manage.

\section{Results}

\subsection{Measures Evaluation}

Before the investigation of the hypotheses, we first examine the data to assess the reliability and validity of the measures employed (Nunnally, 1978; Gerbing \& Anderson, 1988). Table 1 presents the descriptive statistics of the measures while Table 2 reports the results from the reliability and validity assessment.

\section{PLACE TABLE 1 AROUND HERE}

As Table 2 shows we first ran a principal component factor analysis on each construct to check for unidimensionality. Results report high loadings on the intended factors, providing support for this first test. Next, construct validity was assessed through the procedure suggested by Fornell and Larcker's (1981). As Table 2 reports, Average Variance Extracted (AVE) from all measures exceeds the minimum (0.50) requirement for demonstrating convergent validity. Additionally, the AVE for each construct is higher than the squared correlation between that construct and any other construct in the model. Hence, discriminant validity also holds for all constructs.

The next test examines the reliability of the measures and their internal consistency. For this purpose we rely on the composite reliability index. For each measure a 0.6 value or better demonstrates reliable measurements (Bagozzi \& Yi, 1988). Moreover, with Cronbach's alpha coefficients also above the 0.7 threshold (Nunnally, 1978) it is clear that the measures are internally consistent.

\section{PLACE TABLE 2 AROUND HERE}

Finally, because of the single-informant approach, testing for common method bias (CMB) is necessary. To perform this final test we use the Harman's single-factor test, a widely used procedure 
when key informants provide the data (Podsakoff, MacKenzie, Lee, \& Podsakoff, 2003). This test requires performing an Exploratory Factor Analysis (EFA), while constraining the number of extracted factors to only one. This procedure has been repeated for every single set of constructs and the results show that the data do not suffer from CMB (variance explained by a single construct for $\mathrm{KAMO}=39,5 \%$; for organisational structure $=40,1 \%$; for relational capabilities $=36,4 \%$; for relationship quality $=41,2 \%$; and for non-financial outcomes $=44.3 \%$ ). In summary, all measures have satisfactory psychometric properties so analysis can move to the next phase.

\subsection{Competing model testing}

The next step in the analysis is to examine the conceptual model underlying this study against a rival one since in the proposed model organisational structure and relational capabilities have a central nomological status regarding the performance outcomes from KAMO adoption (Bollen \& Long, 1992).

A nonparsimonious rival view would be one suggesting only direct paths from each of the antecedents to the outcomes, thereby making organisational structure and relational capabilities nomologically similar to the adoption of KAMO. Therefore, the rival model, presented in Figure 2 does not allows for indirect effects. Although no one has theorized the rival model, it is implied by the numerous normative discussions regarding the effect of structure and relationship marketing on company performance (e.g. Millman \& Wilson, 1999; Pardo, 1999; Gosselin \& Bowen, 2006; Guesalaga \& Johnston, 2010)

\section{PLACE FIGURE 2 AROUND HERE}

To facilitate the model comparison, given the psychometric qualities of the measures, prior the comparison we first produced summated measures for all major constructs. For instance, for each of the six KAMO dimensions we calculated the simple arithmetic mean (average) from the observed measures leading to a single composite measure per KAMO dimension (Homburg \& Pflesser, 2000). This produces a latent variable of KAMO with six indicators. The same procedure was carried out for relationship quality and financial and non-financial outcomes, given that both theory (e.g. Walter \& Ritter, 2003) and scale purification tests provide evidence that each indicator loads appropriately on the intended latent variable. 


\section{PLACE TABLE 3 AROUND HERE}

Table 3 summarizes the comparison between the proposed and the rival models. The comparison between the two models is done on the following criteria (Morgan \& Hunt, 1994): (1) overall fit of the model as measured by $\chi^{2}, C F I$, NNFI and RMSEA, and (2) ability to explain the variance in outcomes of interest as measured by squared multiple correlations (SQM). Table 3 presents the results showing the superiority of the proposed model over the rival one. Although the overall fit indices of the rival model are acceptable and rather close to those of the proposed model, the fit indicesof the rival model $\left(x^{2}(164)=376.22, \mathrm{p}<.01, \mathrm{CFI}=.94, \mathrm{NNFI}=.95, \mathrm{RMSEA}=.08\right)$ are worse than the proposed model. Moreover, the degree of explained variance for non-financial outcomes is larger in the proposed model as compared to the rival model.

\subsection{Hypotheses Testing}

Having established the superiority of the proposed model, we test the hypotheses using IBM's software package Amos 20.0, which allows for structural equation modelling. Table 4 presents the results of the hypotheses testing. Regarding the overall fit of the model we rely on the $\chi^{2} / \mathrm{df}$ ratio, the Comparative Fit Index (CFI), the Root Mean Square Error of Approximation (RMSEA) and the NonNormed Fit Index (NNFI). The ratio of $\chi^{2}$ over the degrees of freedom (df) is a descriptive measure of overall fit. Values of this ratio smaller than 2 indicate an acceptable model fit (Medsker, Williams, \& Holahan, 1994) although $\chi^{2}$ can be very sensitive to sample size (Bagozzi \& Yi, 2012). CFI is an incremental fit index suggested by Bentler (1990) who recommends a minimum threshold of 0.9 as evidence of good fit. For the root mean square error of approximation (RMSEA) values not exceeding 0.08 are usually considered to indicate a reasonable model fit (Browne \& Cudeck, 1993). However, while RMSEA is regarded as 'one of the most informative fit indices' (Diamantopoulos \& Siguaw, 2000), the size of the sample can affect the ability of the index (Tanaka, 1987). To remedy this, researchers can rely on NNFI (Bentler, 1990; Sharma, Mukherjee, Kumar, \& Dillon, 2005). Values greater than 0.95 for NNFI are considered to indicate good model fit (Hu \& Bentler, 1999). As Table 4 shows, the results from the SEM analysis show that the model fits the data very well since all 
indices and measures satisfy the minimum required figures $\left(x^{2}=468.92, d f=244, \mathrm{p}<.01, \chi^{2} / d f=\right.$ $1.92, \mathrm{CFI}=0.94, \mathrm{RMSEA}=0.06, \mathrm{NNFI}=0.96)$.

Regarding the effect of KAMO adoption on centralisation and formalisation (hypotheses H1a and $\mathrm{H} 1 \mathrm{~b}$ ), from Table 4 is clear that H1a is accepted since the effect on centralisation is significant ( $\beta$ $=-0.15, \mathrm{p}<0.01)$. However, $\mathrm{H} 1 \mathrm{~b}$ is rejected since according to the analysis the adoption of KAMO has a positive effect on formalisation $(\beta=0.23, \mathrm{p}<0.01)$. Moreover, KAMO adoption has also a strong positive effect on information sharing $(\beta=0.29, \mathrm{p}<.01)$ and conflict resolution $(\beta=0.47, \mathrm{p}<$ .01) supporting both $\mathrm{H} 2 \mathrm{a}$ and $\mathbf{H 2} \mathbf{b}$. By contrast, when it comes to the indirect effect of KAMO adoption on relational capabilities through the organisational structure, as Table 4 shows, the analysis confirms only one of the original hypotheses $\left(\mathrm{H} 3 \mathrm{~b}_{\mathrm{C}}\right)$ as the effect of centralisation on conflict resolution abilities is significant and negative. Hence, $\mathrm{H} 3 \mathrm{~b}$ can be only partially accepted. The analysis reveals another significant effect, that of formalisation on information sharing, but as Table 4 shows, formalisation has a positive, effect on information sharing. Thus H3a is all together rejected.

\section{PLACE TABLE 4 AROUND HERE}

The next set of hypotheses investigates how relationship quality, financial and non-financial outcomes reflect the adoption of KAMO and the subsequent effect on the supplier's organisational structure and relationship capabilities. Again, from Table 4 is clear that most of the effects are significant and follow the expected direction. One single exception is observed since the influence of formalisation on relationship quality is significant but positive $(b=0.26)$. Hence, while H4a is partially accepted, hypotheses $\mathrm{H4b}, \mathrm{H5}$ and $\mathrm{H6}$ are fully accepted.

Finally, to investigate whether the span of control moderates the overall KAM effectivenessantecedents link (H7) we employed subgroup analysis (Arnold, 1982). Following standard econometric procedures, using the moderating variable (span of control for Key Accounts), the sample was first sorted in ascending order. Then, the top and bottom $35 \%$ of the cases were selected to obtain two subgroups reflecting firms with a rather high and a rather low span of control respectively. The middle $30 \%$ of the cases are omitted to improve the contrast between the subgroups and hence the power of the subsequent statistical tests (Kohli, 1989). 
To test whether the two subgroups are significantly different regarding organisational structure, relational capabilities, relationship quality and performance outcomes we used the test recommended by Chow (Chow, 1960). Table 5 informs of the results from this analysis. From Table 5 is clear that the span of control does not moderate the relationship between neither relationship quality and financial and non-financial benefits nor the one between organisational structure and relational capabilities. Hence, the results of the analysis fail to support $\mathrm{H} 7$.

\section{Discussion and Implications}

McDonald, Rogers and Woodburn (2000, pp.48-72) describe the evolution of the KAM relationship from lower stages that are transaction focused ("Basic" and "exploratory" phases) to higher levels where the focus is on deepening and strengthening the collaboration between the two parties to their mutual benefit. The authors, like others in the field (cf. Ryals \& Humphries, 2007) explain how it is possible and why the relationship between the supplier and the KA can lack a clear focus on the opportunity for both parties to accrue mutual benefits from strengthening and deepening their collaboration and from adopting a long-term perspective of their business. Instead the two companies can (both) remain focused on the short-term, individual, benefits their own organisation can rip from every single transaction,and ignore the potential for mutual benefits over the long-run.

Although the discourse is on the level of the KA manager, it is clear that the individual manager's objectives and his/her conduct in pursuing them is a reflection of the willingness and readiness of the supplier's management to adapt their solution to accommodate the needs of the customers and, consequently, facilitate the job the of KA manager (cf. McDonald et al., 2000, p.209239). Not surprisingly, although many suppliers pay lip-service to KAM and "upgrade" the status of their sales personnel to that of the "Key Account Manager", they still remain immensely driven by the principles of NAM and the individual exchange with their customer. While trust, customer satisfaction and long-term commitment, the elements in other words of the relationship quality construct, are identified as the major prerequisites for the elevation of the relation between the supplier and the customer to the higher levels of the relationship hierarchy (McDonald et al., 2000), how these three qualities can be developed remains alas without empirical investigation. 
Hence, this is how this study contributes in the KAM literature. Consistent with a relationship marketing based view, this manuscript introduces the adoption of KAMO as the manifestation of the supplier's paradigm shift, which in turn stimulates structural reformation and allows for skills development that jointly enhance the relationship quality between the supplier and the customer. The study also makes a contribution by demonstrating that, besides the financial impact a KAM program has, through better relationship quality the supplier can expect to achieve significant non-financial benefits. Finally this investigation sheds light on the merits from a KAM project independently of the resources available to the supplier. In the following paragraphs we discuss the findings from the investigation in more detail and relatively to the research objectives we discussed earlier in the manuscript. We also highlight how meeting each of the research objectives makes a contribution both for the theory and the practice.

More precisely, the first objective of this investigation is to explore the significance of understanding the relational nature of KAM as an antecedent of structural adjustments and relational capabilities development to facilitate the implementation of the supplier's KAM programs. To meet this first objective, we rely on the adoption of KAMO as the manifestation of the supplier's paradigm shift towards a relationship-marketing approach to design and implement KAM programs (Gounaris \& Tzempelikos 2013). As the analysis has shown, once the pursuit for mutual, long-run benefits drives the implementation of KAM programs, top management shows more commitment and becomes more involved in the effort to meet the needs of the KAs. Not surprisingly, as a result of top management involvement and commitment, inter-functional coordination and support also increase.

A direct consequence of this is on the supplier's organisational structure which transforms to a less centralised, more agile organisation, as the analysis has shown. This is may not be a surprising finding since increased centralisation reduces the supplier's ability to respond promptly to the customer needs. Especially so if, for instance, the KA is a rather geographically dispersed organisation and the supplier's headquarters are located away from the customer's. At the same time though, adopting KAMO seems to result in more formalised structures. This seems to be a surprising result since many empirical studies, especially in the market orientation research stream (cf. Narver \& Slater, 1990, Walker \& Ruekert, 1987), demonstrate that the company's ability to meet the customer's needs is usually associated with less formal structures. However, when the structural transformations are jointly considered they provide the grounds for what Morris, Schindehutte and 
Allen (2006) have called "opportunistic flexibility" to describe a tight-loose approach in management that characterises successful companies. This duality in organisational structuring allows the supplier to maintain discipline through formal structures and procedures while enabling entrepreneurial behaviours through decentralisation (Collins, 2001). The documentation of the effect on the supplier's organisational structure from the adoption of a relationship marketing paradigm in KAM initiatives remains tremendously slim in the pertinent literature.

This "freedom within a framework" (Morris et al., 2006) situation that KAMO adoption produces sets the grounds for certain relational skills to flourish, namely information sharing and conflict resolution. Both are important as enablers of a close, mutually beneficial relationship between the supplier and the KA (Ryals \& Humphries, 2007; Richards \& Jones, 2009; Millman \& Wilson, 1999). More specifically, while KAMO adoption directly nourishes both kinds of relational skills, the formalisation of the organisational structure boosts information sharing (reflecting the benefit for information sharing from procedural formality) but has no significant impact on conflict resolution skills. The latter however are strengthened as the organisational structure becomes more decentralised reflecting for instance the benefits of allowing decision-making to happen locally where the individual KA manager has a better understanding of the customer needs. The composition of these indirect effects through organisational structure on the supplier's relational skills that the analysis has revealed consolidates further the previous conclusion regarding the need to attune the structure of the organisation to accommodate the relationship marketing perspective a KAM program requires.

The second objective is to examine the consequences of this paradigm shift on the level of the relationship quality between the supplier and the KA as well as on the performance of the supplier. Previous studies consider KAs as "valuable assets" the suppliers should manage to improve their performance through a longer-term relationship (Ivens \& Pardo, 2007). The analysis presented earlier in the manuscript offers the necessary empirical confirmation. Our findings suggest that KAMO adoption ignites a process of organisational restructuring and the two combined allow the supplier to develop certain relational skills. As a result of these skills and the organisational restructuring the relationship quality between the supplier and the KA improves. Once the customer is satisfied with the relationship, trusts the suppliers and, most importantly, becomes committed to the supplier, then the supplier's financial and non-financial performance will also improve. Again, this is a significant contribution in the KAM theory since these are the first empirical data to demonstrate the process 
through which a supplier benefits from KAM not only in terms of sales and market share as well as profitability and ROI but also in terms of reference value, know-how development or process efficiency.

The last objective was to investigate whether the availability of sufficient managerial manpower has or not a moderation effect on the outcomes of the KAM initiative. The hypothesised moderation effect grounds on the Resource Based View of the firm and is well documented in pertinent literature (cf. Homburg et al., 2002). Span of control captures a significant resource of the company, namely availability of managerial resources to allocate to different accounts. The lower the span of control the more focused the account manager is on resolving the issues arising in the relationship between the supplier and the customer, improving thus the ability of the former to respond to the needs and wants of the KA. As a result, the supplier's performance should improve. However, the analysis has failed to confirm this moderation. In other words, adopting KAMO, restructuring the organisation accordingly and developing certain relational skills is equally beneficial for firms with both lower and higher levels of span of control.

From the perspective of the Resource Based View theory, the only possible explanation for this finding is that this transition in its entirety represents a potential basis for developing a competitive advantage in itself. Adopting a relationship marketing perspective in managing matters arising and requirements coming from KAs calls for a paradigm shift. For instance, top management has to become heavily committed and involved with the effort to satisfy the needs of KAs, develop a KA orientation throughout the firm to improve coordination in meeting the KAs' needs and become willing to invest as necessary to produce customised solutions for the KAs. Moreover, the organisational restructuring and the development of relational skills complement this paradigm shift and give practical meaning to the changes the supplier is undergoing. This entire range of changes, once completed, represent a sustainable competitive advantage, which can be so strong as to allow even smaller suppliers with fewer managerial resources (larger span of control) to remain effective in managing their relationship with their KAs.

Besides the theoretical contribution, this study has some significant implications for practitioners too. The first important implication concerns the organisational consequences that KAMO adoption fosters. For instance, decentralising decision making is not always easy. Managers at 
middle or even lower levels need to be willing to undertake the responsibility for making decisions and must also have the necessary know-how to do so (Hurley \& Hult, 1998). Neither of these two requirements is always easy to meet. A serious investment in managerial time to train managers and promote the orientation towards the KAs is required. Likewise, monetary resources must become available to attract and sustain talent is also necessary to accomplish this paradigm shift. Yet, this study makes clear the potential benefit from such investment.

The other important implication is the nature of the benefit top management may expect to accrue from implementing KAM. Insofar, the extant literature informs on the positive effect KAM produces for the supplier's financial performance. Adopting KAMO allows the supplier to improve the relationship quality with the KA. Hand in hand with improved relationship quality also come stronger reference value, better know how development and more efficient processes and internal communications. All these benefits together can be perceived as crucial strategic assets, which safeguard the long term duration of the relationship with the present portfolio of KAs, while shaping the conditions for improving the supplier's attractiveness for other customers with whom the supplier has little or no business.

\section{Limitations and Future Research}

In spite of the significant contributions this study makes, some limitations are worth noting and addressing, albeit these limitations do not contract the value for academics and practitioners from this investigation. The first considerable limitation is the focus on the supplier's internal environment. Competitive intensity, technology change rate and technological turbulence are some of the external environment characteristics this investigation does not address. The reason for not addressing them is that management has little control over the external environment (Jaworski \& Kohli, 1993). Yet, given the lack of moderation from span of control, incorporating such dimensions in future research will allow academics to produce a more informative picture of the conditions under which a KAM can help suppliers acquire a decisively superior competitive position. Research towards this direction is strongly recommended.

The second limitation refers to the research design and the use of a single-informant from only the supplier's part. Although this research design serves well the study's objectives, a hierarchical 
design that would allow incorporating KA view would benefit our understanding of the relational KAM outcomes. Thus, future research towards this direction is equally very welcome.

Another open issue is the complexity of orientations that a supplier adopts. The literature has claimed that firms have different orientations at the same time because many firms have segmented their customer base with the aim to differentiate their offering to meet different customer groups' needs (Hedaa \& Ritter, 2005). Thus, one could ask how KAMO can work with different orientations such as for instance entrepreneurial orientation. Such studies can produce valuable insights regarding the different values that can coexist in a single organisation and how these can affect the performance of a KAM program.

Finally, another interesting direction for future research entails the effort to produce models of optimisation. For instance, centralisation / decentralisation is not a "black-white" situation. Hence, the effect of centralisation on, for instance relationship quality is not necessarily neither linear nor monotonic. Likewise the amount of information sharing that allows the supplier to benefit from the relationship with a KA is probably subject to similar concerns. Hence, future research designed to unveil the optimum levels for such factors will allow managers to fine tune their efforts towards collaborative KAM relationships and thus is highly recommended. 


\section{References}

Abratt, R. \& Kelly, P.M. (2002). Customer-supplier partnerships-perceptions of a successful key account management program. Industrial Marketing Management, 31(4), 467-476.

Achrol, R. S. (1991). Evolution of the Marketing Organization: New Forms for Turbulent Environments. Journal of Marketing, 55(October), 77-93.

Aiken, M., \& Hage, J. (1968). Organisational 1 independence and intraorganisational structure. American Sociological Review, 33, 912-930.

Anderson, J.C. \& Narus, J.A. (1990). A Model of Distributor Firm and Manufacturer Firm Working Partnerships. Journal of Marketing, 54(January), 42-58.

Arnold, H. (1982). Moderator Variables: A Clarification of Conceptual, Analytic, and Psychometric Issues. Organisational Behaviour and Human Performance, 29(April), 143-174

Bagozzi, R.P., \& Yi, Y. (1988). On the Evaluation of Structural Equation Models. Journal of the Academy of Marketing Science, 16(Spring), 74-94.

Bagozzi, R.P., \& Yi, Y. (2012). Specification, evaluation, and interpretation of structural equation models. Journal of the Academy of Marketing Science, 40, 8-34.

Barney, J.B. (1991). Firm resources and sustained competitive advantage. Journal of Management, 17(1), 99-120.

Bentler, P.M. (1990). Comparative Fit Indexes in Structural Models. Psychological Bulletin, 107(2), $238-46$

Boles, J., Johnston, W., \& Gardner, A. (1999). The selection and organization of national accounts: a north American perspective. Journal of Business \& Industrial Marketing, 14(4), 264-275.

Bollen, K. \& Long, J.S.(1992). Tests for structural equation models: introduction. Sociological Methods \& Research, 21, November, 123-131.

Browne, M.W. \& Cudeck, R. (1993). Alternative Ways of Assessing Model Fit. In Testing Structural Equation Models. Eds. K. A. Bollen \& J. S. Long. Newbury Park, CA: Sage.

Cannon, J.P., \& Perreault Jr., W.D. (1999). Buyer-seller relationships in business markets. Journal of Marketing Research, 36(November), 439-460.

Caspedes, F.V. (1993). Coordinating sales and marketing in consumer goods firms. Journal of Consumer Marketing, 10(2), 37-55.

Chow, G. (1960). Tests of Equality between Sets of Coefficients in two Two Linear Regressions. Econometrica, 28(3), 591-605.

Collins, J. (2001). Good to great: Why some companies make the leap ... and others don't, Harper Business, New York.

Crosby, L.A., Evans, K.R. \& Cowles, D. (1990). Relationship Quality in Services Selling: An Interpersonal Influence Perspective. Journal of Marketing, 54(July), 68-81.

Day, G. S. (2000). Managing market relationships. Journal of the Academy of Marketing Science, 28(1), 24-30. 
Davies, I.A., \& Ryals, L.J. (2009). A stage model for transitioning to KAM. Journal of Marketing Management, 25(9-10), 1027-1048

Diamantopoulos, A. \& Siguaw, J.A. (2000). Introducing LISREL. London: Sage Publications

Doney, P.M., \& Cannon, J.P. (1997). An examination of the nature of trust in buyer-seller relationships. Journal of Marketing, 61(April), 35-51.

Dorsch, M.J., Swanson, S.R., \& Kelley, S.W. (1998). The Role of Relationship Quality in the Stratification of Vendors as Perceived by Customers. Journal of the Academy of Marketing Science, 26(Spring), 128-142.

Dyer, J.H., \& Singh, H. (1998). The relational view: Cooperative strategy and sources of interorganisational competitive advantage. Academy of Management Review, 23(4), 660-679.

Fornell, C. \& Larcker, D.F. (1981). Evaluating structural equation models with unobservable variables and measurement error. Journal of Marketing Research, 18(February), 39-50.

Garbarino, E., \& Johnson, M.S. (1999). The Different Roles of Satisfaction, Trust, and. Commitment in Customer Relationships. Journal of Marketing, 63(2), 70-87

Gerbing, D. \& Anderson, J. (1988). An updated paradigm for scale development incorporating unidimensionality and its assessment. Journal of Marketing Research, 25(May), 186-192.

Gosselin, D.P. \& Bauwen, G.A. (2006). Strategic account management: customer value creation through customer alignment. Journal of Business \& Industrial Marketing, 21(6), 376-385.

Grönroos, C. (1994). Quo Vadis, Marketing? Toward a Relationship Marketing Paradigm. Journal of Marketing Management, 10 (5), 347-360.

Guesalaga, R. \& Johnston, W. (2010) What's next in key account management research? Building the bridge between the academic literature and the practitioners' priorities. Industrial Marketing Management, 39(7), 1063-1068

Gounaris, S., \& Tzempelikos, N. (2013). Key Account Management Orientation and its Implications - A Conceptual and Empirical Examination. Journal of Business-to-Business Marketing, 20(1), 3350.

Hair, J.F., Anderson, R.E., Tatham, R.L., \& Black, W.C. (1998). Multivariate Data Analysis. (5th ed.), Prentice-Hall, Upper Saddle River, NJ.

Hall, R.H., Haas, J.E., \& Johnson, N.J. (1967). Organisational size, complexity, and formalisation. American Sociological Review, 32(6), 903-911.

Hedaa, L., \& Ritter, T. (2005). Business relationships on different waves: paradigm shifts and marketing orientation revisited. Industrial Marketing Management, 34(7), 714-721.

Heide, J.B. \& John, G. (1992). Do norms matter in marketing relationships? Journal of Marketing, 56(April), 32-44.

Heimeriks, K., \& Duysters, G. (2007). Alliance capability as a mediator between experience and alliance performance: An empirical investigation into the alliance capability development process. Journal of Management Studies, 44(1), 25-49. 
Homburg, C. \& Pflesser, C. (2000). A Multiple-Layer Model of Market-Oriented Organisational Culture: Measurement Issues and Performance Outcomes. Journal of Marketing Research, 37(November), 449-462.

Homburg, C., Workman, Jr. J.P. \& Jensen, O. (2000) Fundamental Changes in Marketing Organization: The Movement Toward a Customer-Focused Organisational Structure. Journal of the Academy of Marketing Science, 28(4), 459-478.

Homburg, C., Workman Jr., J.P. \& Jensen, O. (2002) A configurational perspective of key account management. Journal of Marketing, 66(April), 38-60.

Hu, L.T. \& Bentler, P.M. (1999). Cutoff Criteria for Fit Indexes in Covariance Structure Analysis: Conventional Criteria Versus New Alternatives. Structural Equation Modeling, 6(1), 1-55.

Hult, G.T.M.., Ketchen, D.J., \& Slater, S.F. (2005). Market orientation and performance: An integration of disparate approaches. Strategic Management Journal, 26(12), 1173-1181.

Huntley, J.K. (2006). Conceptualization and measurement of relationship quality: Linking relationship quality to actual sales and recommendation intention. Industrial Marketing Management, 35, $703-714$

Hurley, R.F., \& Hult, T.G. (1998). Innovation, Market Orientation, and Organisational Learning: An Integration and Empirical Examination. Journal of Marketing, 62(July), 42-54.

Ivens, B.S. \& Pardo, C. (2007). Are key account relationships different? Empirical results on supplier strategies and customer reactions. Industrial Marketing Management, 36(4), 470-482.

Jayachandran, S., Sharma, S., Kaufman, P., \& Raman, P. (2005). The role of relational information processes and technology use in customer relationship management. Journal of Marketing, 69(4), $177-192$.

Jaworski, B.J., \& Kohli, A.K. (1993) Market orientation: antecedents and consequences. Journal of Marketing, 57(July), 53-70.

John, G. \& Reve, T. (1982) The Reliability and Validity of Key Informant Data from Dyadic Relationships in Marketing Channels. Journal of Marketing Research, 19(November), 517-524.

Jones, E., Dixon, A., Chonko, L., \& Cannon, J. (2005). Key accounts and team selling: a review, framework, and research agenda. Journal of Personal Selling \& Sales Management, 25(2), 181-198

Jones, E., Richards, K.A., Halstead, D., \& Fu, F. Q. (2009). Developing a strategic framework of key account performance. Journal of Strategic Marketing, 17(3), 221-235.

Kahn, K.B., \& Mentzer, J.T. (1998). Marketing's integration with other departments. Journal of Business Research, 42(1), 53-62.

Kohli A. (1989). Effects of the Supervisory Behaviour: The Role of Individual Differences Among Salespeople. Journal of Marketing, 53(4), 40-50

Leuthesser, L. (1997). Supplier relational behavior: an empirical assessment. Industrial Marketing Management, 26, 245-254.

Makadok, R. (2001), Toward a Synthesis of the Resource-Based View and Dynamic-Capability Views of Rent Creation. Strategic Management Journal, 22(5), 387-401 
McDonald, M., Rogers, B. \& Woodburn, D. (2000). Key accounts: How to manage them profitably. Butterworth-Heinemann, Oxford, UK.

McDonald, M., Millman, T. \& Rogers, B. (1997) Key account management: theory, practice and challenges. Journal of Marketing Management, 13(November), 737-757.

Medsker, G.J., Williams, L.J., \& Holahan, P.J. (1994). A review of current practices for evaluating causal models in organisational behavior and human resources management research. Journal of Management, 20(2), 439-464

Millman, T. \& Wilson, K. (1995). From key account selling to key account management. Journal of Marketing Practice: Applied Marketing Science, 1(1), 9-21.

Millman, T. \& Wilson, K. (1999). Processual issues in key account management: underpinning the customer-facing organization. Journal of Business \& Industrial Marketing, 14(4), 328-337.

Mohr J.S. \& Spekman, R. (1994). Characteristics of partnership success: partnership attributes communication behaviour, and conflict resolution techniques. Strategic Management Journal, 15, 135-152.

Montgomery, D.B. \& Yip, G.S. (2000). The challenge of global customer management. Marketing Management, 9 (4), 22-29.

Morgan, R.M., \& Hunt, S.D. (1994). The commitment-trust theory of relationship marketing. Journal of Marketing, 58(July), 20-38.

Morris, M.H., Schindehutte, M. \& Allen, J. (2006). Balanced control systems as a mechanism for achieving corporate entrepreneurship. Journal of Managerial Issues, 18(4), 468-495.

Narver, J.C., \& Slater, S.F. (1990). The effect of a market orientation on business profitability. Journal of Marketing, 54(August), 20-35.

Ngo, L.V. \& O'Cass, A. (2009). Creating value offerings via operant resource-based capabilities. Industrial Marketing Management, 38, 45-59.

Nunnally, J.C. (1978). Psychometric Theory (2nd ed.), New York, McGraw-Hill.

Ojasalo, J. (2001). Key account management at company and individual levels in business-to-business relationships. Journal of Business \& Industrial Marketing, 16(3), 199-218.

Pardo, C. (1999) Key account management in the business-to-business field: a French overview. Journal of Business \& Industrial Marketing, 14(4), 276-290.

Parvatiyar, A. \& Sheth, J. (2000). The domain and conceptual foundations of relationship marketing. in Sheth J. and Parvatiyar A. (eds), Handbook of Relationship Marketing, Sage Publictions, 3-38

Pels, J. (1992). Identification and management of key clients. European Journal of Marketing, 26(5), $5-21$.

Phillips, L. (1981). Assessing measurement error in key informant reports: A methodological note on organisational analysis in marketing. Journal of Marketing Research, 18(4), 395-415

Piercy, N.F. (2006). The Strategic Sales Organization. The Marketing Review, 1, 3-28 
Podsakoff, P.M., MacKenzie, S.M., Lee, J., \& Podsakoff, N.P. (2003). Common method variance in behavioral research: A critical review of the literature and recommended remedies. Journal of Applied Psychology, 88, 879-903

Pressey, A., Tzokas, N., \& Winklhofer, H. (2007). Strategic purchasing and the evaluation of "problem" key supply relationships: what do key suppliers need to know?. Journal of Business \& Industrial Marketing, 22(5), 282 - 294

Reichheld, F.F. (1996). The Loyalty Effect: The Hidden Force Behind Growth, Profits, and Lasting Value. Boston: Harvard Business School Press.

Richards, K.A., \& Jones, E. (2009). Key account management: Adding elements of account fit to integrative theoretical framework. Journal of Personal Selling \& Sales Management, 29(4), 305320

Ryals, L.J., \& Humphries, A.S. (2007). Managing Key Business-to-Business Relationships: What Marketing Can Learn From Supply Chain Management. Journal of Service Research, 9(4), 312326.

Salojärvi, H., Sainio, L-M. \& Tarkiainen, A. (2010) Organisational factors enhancing customer knowledge utilization in the management of key account relationships. Industrial Marketing Management, 39 (8), 1395-1402.

Shapiro, B.P. \& Moriarty, R.T. (1984). Support systems for National Account Management programs. Marketing Science Institute Working Paper No. 84-102. Cambridge, MA: Marketing Science Institute.

Shapiro, B.P. \& Wyman, J (1981). New ways to reach your customers. Harvard Business Review, (July-August), 103-110.

Sharma, S., Mukherjee, S., Kumar, A., \& Dillon, W.R. (2005). A simulation study to investigate the use of cutoff values for assessing model fit in covariance structure models. Journal of Business Research, 58(7), 935-943

Spencer, R. (1999). Key accounts: Effectively managing strategic complexity. Journal of Business \& Industrial Marketing, 14(4), 291-309.

Srivastava, R.K., Shervani, T.A., \& Fahey, L. (1998). Market-based assets and shareholder value: A framework for analysis. Journal of Marketing, 62(1), 2-18.

Storbacka, K., Ryals, L., Davies, I.A., \& Nenonen, S. (2009). The changing role of sales: viewing sales as a strategic, cross-functional process. European Journal of Marketing, 43(7/8), 890-906

Tanaka, J.S. (1987). "How big is big enough?": Sample size and goodness of fit in structural equation models with latent variables. Child Development, 58, 134-146

Theoharakis, V., Sajtos, L. \& Hooley, G. (2009). The strategic role of relational capabilities in the business-to-business service profit chain. Industrial Marketing Management, 38, 914-9

Vargo, S.L., \& Lusch, R.F. (2008). From goods to service(s): Divergences and convergences of logics. Industrial Marketing Management, 37(3), 254-259 
Vorhies, D.W., Harker, M. \& Rao, C.P. (1999). The capabilities and performance advantages of market-driven firms. European Journal of Marketing, 33(11/12), 1171-1202.

Walker, O.C., Jr., \& Ruekert, R.W. (1987). Marketing's Role in the Implementation of Business Strategies: A Critical Review and Conceptual Framework. Journal of Marketing, 51(July), 15-33.

Walter, A., \& Ritter, T. (2003). The Influence of Adaptations, Trust, and Commitment on ValueCreating Functions of Customer Relationships. Journal of Business \& Industrial Marketing, 18(4/5), 353-365

Webster, F.E. (1992). The changing role of marketing in the corporation. Journal of Marketing, 56(October), 1-17.

Weilbaker, D.C. \& Weeks, W.A. (1997). The evolution of national account management: a literature perspective, Journal of Personal Selling \& Sales Management, 17(4), 49-59.

Wengler, S., Ehret, M. \& Saab, S. (2006). Implementation of Key Account Management: Who, why, and how? An exploratory study on the current implementation of Key Account Management programs. Industrial Marketing Management, 35(1), 103-112.

Wernerfelt, B. (1984). A resource-based view of the firm. Strategic Management Journal, 5(2), $171-180$.

Woodburn, D., \& McDonald, M. (2011). Key Account Management: The Definitive Guide. (3rd ed.), John Wiley \& Sons

Workman, J.P., Homburg, C. \& Jensen, O. (2003) Intraorganisational determinants of key account management effectiveness. Journal of the Academy of Marketing Science, 31(1), 3-21.

Zupancic, D. (2008) Towards an integrated framework of key account management. Journal of Business \& Industrial Marketing, 23(5), 323-331 
Appendix: Measures

\begin{tabular}{|c|c|c|c|}
\hline Construct & Items & $\mathrm{M} / \mathrm{SD}$ & $\begin{array}{l}\text { Item } \\
\text { loading }\end{array}$ \\
\hline \multicolumn{4}{|c|}{ Key Account Management Orientation } \\
\hline \multirow{5}{*}{$\begin{array}{l}\text { Customer } \\
\text { Orientation }^{\mathrm{a}}\end{array}$} & Satisfying the needs of our key accounts is a major objective for us & $5.47 / 1.21$ & 0.56 \\
\hline & We always monitor the extent that we satisfy our key accounts' needs & $5.27 / 1.22$ & 0.87 \\
\hline & $\begin{array}{l}\text { We try to deliver superior value to our key accounts through our } \\
\text { products/services }\end{array}$ & $5.62 / 1.14$ & 0.77 \\
\hline & We frequently measure the level of satisfaction of our key accounts & $5.10 / 1.35$ & 0.86 \\
\hline & We pay a lot of attention on the after-sale service of our key accounts & $5.69 / 1.32$ & 0.77 \\
\hline \multirow{5}{*}{$\begin{array}{l}\text { Top- } \\
\text { Management } \\
\text { Commitment }^{\text {a }}\end{array}$} & $\begin{array}{l}\text { Top management affirms the importance of KAM as a major strategical } \\
\text { orientation for the company }\end{array}$ & $5.40 / 1.20$ & 0.82 \\
\hline & Top management sets an example to KAM for the rest of the organization & $5.42 / 1.19$ & 0.89 \\
\hline & $\begin{array}{l}\text { Top management closely overviews all the activities concerning the } \\
\text { management of our key accounts }\end{array}$ & $5.61 / 1.16$ & 0.84 \\
\hline & $\begin{array}{l}\text { Top management has no hesitation to spend a lot of time in order to } \\
\text { contribute in the management of our key accounts }\end{array}$ & $5.52 / 1.13$ & 0.81 \\
\hline & $\begin{array}{l}\text { Top management always stresses the importance that all units can } \\
\text { contribute in delivering value to our key accounts }\end{array}$ & $5.35 / 1.17$ & 0.86 \\
\hline \multirow{4}{*}{$\begin{array}{l}\text { Inter- } \\
\text { functional } \\
\text { Coordination }^{\mathrm{a}}\end{array}$} & All units share information with regard to key accounts & $5.29 / 1.33$ & 0.83 \\
\hline & $\begin{array}{l}\text { All units realize that can contribute in the delivering of superior value to } \\
\text { key accounts }\end{array}$ & $4.98 / 1.31$ & 0.87 \\
\hline & $\begin{array}{l}\text { All units are willing to contribute when a problem of a key account } \\
\text { occurs }\end{array}$ & $5.18 / 1.25$ & 0.89 \\
\hline & $\begin{array}{l}\text { There is integration among the different units in order to satisfy the key } \\
\text { accounts' needs }\end{array}$ & $5.11 / 1.26$ & 0.88 \\
\hline \multirow{6}{*}{$\begin{array}{l}\text { Ability to } \\
\text { Customization } \\
\text { a }\end{array}$} & We adapt our products/ services according to our key accounts' needs & $4.92 / 1.33$ & 0.66 \\
\hline & We respond immediately to our key accounts' problems & $5.78 / 0.99$ & 0.77 \\
\hline & $\begin{array}{l}\text { We adapt the level of our service quality according to our key accounts' } \\
\text { needs }\end{array}$ & $5.35 / 1.05$ & 0.77 \\
\hline & (We adapt our pricing policy to our key accounts) & $4.95 / 1.87$ & 0.41 \\
\hline & We adapt our internal processes in order to meet our key accounts' needs & $4.87 / 1.26$ & 0.73 \\
\hline & We frequent and informally communicate with our key accounts & $6.09 / 0.91$ & 0.65 \\
\hline \multirow{5}{*}{$\begin{array}{l}\text { Top- } \\
\text { Management } \\
\text { Involvement }^{\mathrm{a}}\end{array}$} & $\begin{array}{l}\text { Top-management allocates the required resources (money, time, } \\
\text { personnel) for the KAM function }\end{array}$ & $5.14 / 1.09$ & 0.75 \\
\hline & $\begin{array}{l}\text { Top-management systematically monitors the KAM function within the } \\
\text { company }\end{array}$ & $5.72 / 1.05$ & 0.77 \\
\hline & $\begin{array}{l}\text { Top-management interprets, when necessary, in order to find solutions to } \\
\text { problems that our key accounts face }\end{array}$ & $5.46 / 1.09$ & 0.83 \\
\hline & $\begin{array}{l}\text { Top-management actively participates in the designing of activities } \\
\text { regarding our key accounts }\end{array}$ & $5.59 / 1.07$ & 0.82 \\
\hline & $\begin{array}{l}\text { Top-management compensates/ rewards the actions and initiatives that } \\
\text { lead to the development of the relationships with our key accounts }\end{array}$ & $4.88 / 1.28$ & 0.73 \\
\hline \multirow{3}{*}{$\begin{array}{l}\text { Inter- } \\
\text { functional } \\
\text { support }^{\mathrm{a}}\end{array}$} & $\begin{array}{l}\text { The other units contribute when needed for improving the management } \\
\text { of our key accounts }\end{array}$ & $5.22 / 1.13$ & 0.79 \\
\hline & $\begin{array}{l}\text { The managers who are responsible for managing our accounts have to try } \\
\text { hard in order to obtain help from other units regarding our key accounts } \\
\text { (R) }\end{array}$ & $5.19 / 1.37$ & 0.86 \\
\hline & KAM is viewed as 'competitor' by other functional units (R) & $5.08 / 1.39$ & 0.87 \\
\hline \multicolumn{4}{|c|}{ Organisational structure } \\
\hline
\end{tabular}

Centralization $^{\mathrm{a}}$ there can be little action taken here until a supervisor approves a decision $4.62 / 1.65 \quad 0.83$ 


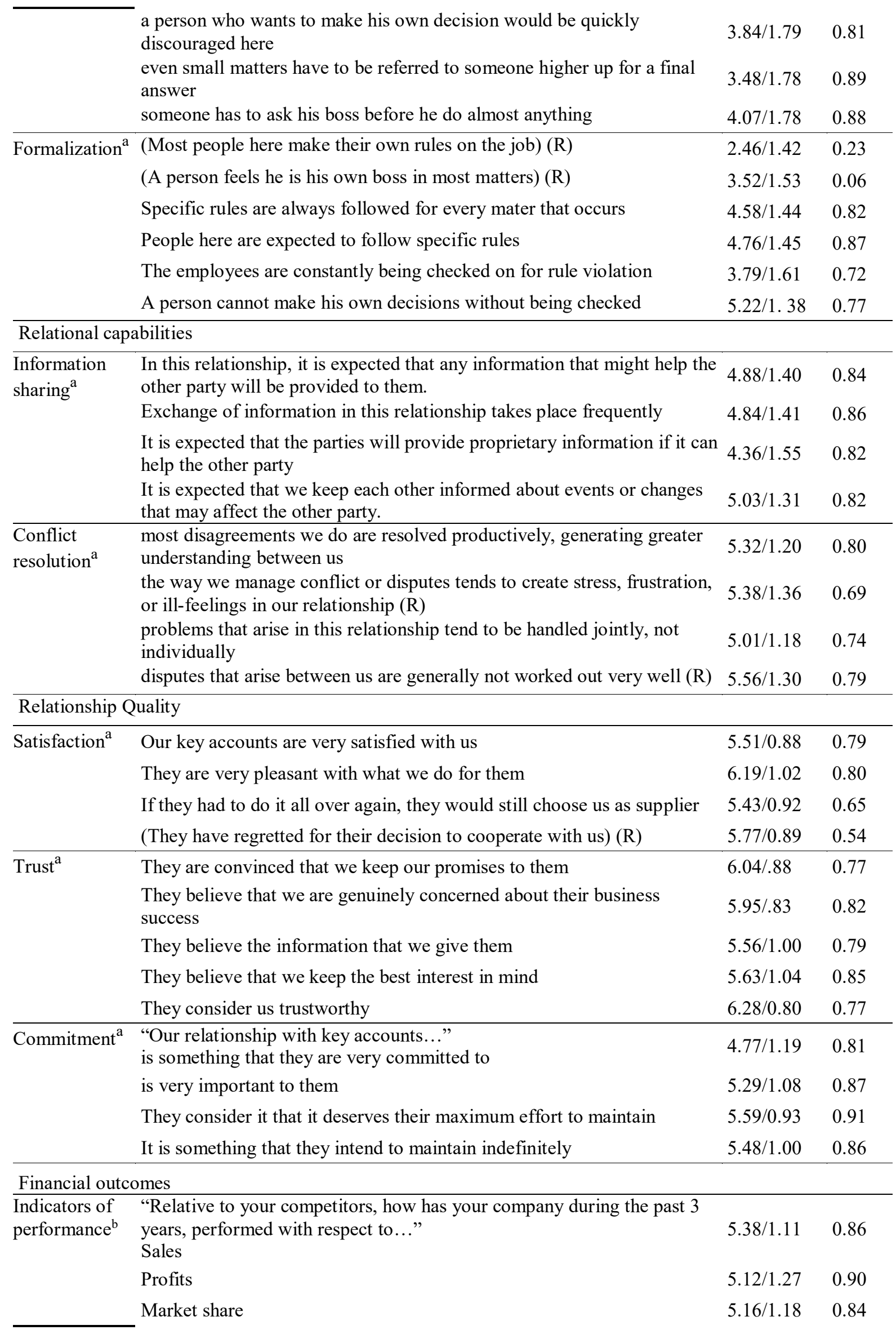




\begin{tabular}{|c|c|c|c|}
\hline \multicolumn{4}{|c|}{ Non-financial outcomes } \\
\hline \multirow[t]{4}{*}{$\begin{array}{l}\text { Reference } \\
\text { value }^{\mathrm{a}}\end{array}$} & $\begin{array}{l}\text { "Our relationship with key accounts..." } \\
\text { Enhances our reputation }\end{array}$ & $6.10 / 0.91$ & 0.90 \\
\hline & Improves the company's status & $6.05 / 0.98$ & 0.89 \\
\hline & Reduces key account's potential risk to work with us & $5.86 / 1.14$ & 0.89 \\
\hline & Helps us become well-known in the market & $5.45 / 1.24$ & 0.76 \\
\hline \multirow[t]{4}{*}{$\begin{array}{l}\text { Know how } \\
\text { development }\end{array}$} & $\begin{array}{l}\text { "Our relationship with key accounts..." } \\
\text { Force us to upgrade the level of our products/services }\end{array}$ & $5.84 / 1.01$ & 0.88 \\
\hline & Makes us seeking ideas for product/service improvement & $5.73 / 1.08$ & 0.92 \\
\hline & Leads us to learn about technological advances & $5.73 / 1.03$ & 0.90 \\
\hline & Leads us to try to improve our operations & $5.66 / 1.07$ & 0.78 \\
\hline \multirow[t]{3}{*}{$\begin{array}{l}\text { Processes' } \\
\text { efficiency }^{\mathrm{a}}\end{array}$} & $\begin{array}{l}\text { "Our relationship with key accounts..." } \\
\text { Facilitates the production process of our product/services }\end{array}$ & $5.32 / 1.20$ & 0.88 \\
\hline & Improves the internal functional integration & $5.09 / 1.22$ & 0.89 \\
\hline & Facilitates the evaluation of our performance & $4.99 / 1.27$ & 0.84 \\
\hline \multirow{4}{*}{$\begin{array}{l}\text { Intra-firm } \\
\text { communication } \\
\text { a }\end{array}$} & $\begin{array}{l}\text { "Our relationship with key accounts..." } \\
\text { Facilitates the communication between the different units of the company }\end{array}$ & $4.61 / 1.26$ & 0.90 \\
\hline & We respond immediately to our key accounts' problems & $4.36 / 1.33$ & 0.93 \\
\hline & We adapt our internal processes in order to meet our key accounts' needs & $4.45 / 1.38$ & 0.95 \\
\hline & We frequent and informally communicate with our key accounts & $4.45 / 1.38$ & 0.93 \\
\hline
\end{tabular}

Firm size

Number of employees How many employees in total work in your firm?

${ }^{a}$ Seven-point scale with anchors $1=$ totally disagree and $7=$ totally agree

${ }^{b}$ Seven-point scale with anchors $1=$ much worse and $7=$ much better

Note: Scale items not retained are indicated in parentheses. (R) denotes a reverse-coded item 


\begin{tabular}{|c|c|c|c|c|c|c|c|c|c|c|c|c|c|c|c|c|c|c|c|c|}
\hline & Mean & S.D & (1) & (2) & (3) & (4) & (5) & (6) & (7) & (8) & (9) & (10) & (11) & (12) & (13) & (14) & (15) & (16) & (17) & (18) \\
\hline Customer orientation (1) & 5.42 & 1.05 & 1 & & & & & & & & & & & & & & & & & \\
\hline Top-management commitment (2) & 5.46 & 0.99 & $.65 * *$ & 1 & & & & & & & & & & & & & & & & \\
\hline Inter-functional coordination (3) & 5.14 & 1.11 & $.56 * *$ & $.56 * *$ & 1 & & & & & & & & & & & & & & & \\
\hline Ability to customization (4) & 5.40 & 0.79 & $.63 * *$ & $.60 * *$ & $.58 * *$ & 1 & & & & & & & & & & & & & & \\
\hline Top-management involvement (5) & 5.36 & 0.87 & $.60 * *$ & $.68 * *$ & $.62 * *$ & $.64 * *$ & 1 & & & & & & & & & & & & & \\
\hline Inter-functional support (6) & 5.16 & 1.06 & $.12 *$ & $.13 *$ & $.30 * *$ & $.19 * *$ & $.19 * *$ & 1 & & & & & & & & & & & & \\
\hline Centralization (7) & 4,00 & 1,49 & -.06 & -.067 & -.10 & -.05 & -.06 & $-.24 * *$ & 1 & & & & & & & & & & & \\
\hline Formalization (8) & 4,59 & 1,19 & $.25 * *$ & $.25 * *$ & $.25 * *$ & $.22 * *$ & $.23 * *$ & -.08 & $.32 * *$ & 1 & & & & & & & & & & \\
\hline Information sharing (9) & 4.78 & 1.18 & $.27 * *$ & $.22 * *$ & $.22 * *$ & $.28 * *$ & $.31 * *$ & .06 & .05 & $.20 * *$ & 1 & & & & & & & & & \\
\hline Conflict resolution (10) & 5.32 & 0.95 & $.36 * *$ & $.21 * *$ & $.41 * *$ & $.38 * *$ & $.42 * *$ & $.30 * *$ & $-.16 * *$ & .03 & $.28 * *$ & 1 & & & & & & & & \\
\hline Satisfaction (11) & 5.57 & 0.77 & $.52 * *$ & $.43 * *$ & $.48 * *$ & $.51 * *$ & $.52 * *$ & $.20 * *$ & $-.16 * *$ & $.14 *$ & $.28 * *$ & $.52 * *$ & 1 & & & & & & & \\
\hline Trust (12) & 5.89 & 0.73 & $.42 * *$ & $.36 * *$ & $.43 * *$ & $.48 * *$ & $.46 * *$ & $.26 * *$ & $-.11 *$ & $.18 * *$ & $.32 * *$ & $.53 * *$ & $.71 * *$ & 1 & & & & & & \\
\hline Commitment (13) & 5.28 & 0.90 & $.38 * *$ & $.29 * *$ & $.42 * *$ & $.41 * *$ & $.45 * *$ & $.22 * *$ & $-.19 * *$ & $.16 * *$ & $.30 * *$ & $.48 * *$ & $.61 * *$ & $.65 * *$ & 1 & & & & & \\
\hline Reference value (14) & 5.92 & 0.92 & $.29 * *$ & $.32 * *$ & $.26 * *$ & $.37 * *$ & $.32 * *$ & .01 & .04 & $.15 * *$ & $.13 *$ & $.19 * *$ & $.26 * *$ & $.25 * *$ & $.21 * *$ & 1 & & & & \\
\hline Know-how development (15) & 5.76 & 0.96 & $.39 * *$ & $.40 * *$ & $.39 * *$ & $.43 * *$ & $.41 * *$ & .06 & -.03 & $.22 * *$ & $.21 * *$ & $.21 * *$ & $.34 * *$ & $.32 * *$ & $.32 * *$ & $.51 * *$ & 1 & & & \\
\hline Processes' Efficiency (16) & 5.13 & 1.07 & $.33 * *$ & $.28 * *$ & $.26 * *$ & $.36 * *$ & $.39 * *$ & -.08 & .09 & $.24 * *$ & $.29 * *$ & $.19 * *$ & $.30 * *$ & $.27 * *$ & $.29 * *$ & $.43 * *$ & $.56 * *$ & 1 & & \\
\hline Internal communication (17) & 4.47 & 1.23 & $.32 * *$ & $.33 * *$ & $.38 * *$ & $.34 * *$ & $.44 * *$ & -.03 & $.13 *$ & $.29 * *$ & $.26 * *$ & $.20 * *$ & $.33 * *$ & $.25 * *$ & $.31 * *$ & $.36 * *$ & $.49 * *$ & $.72 * *$ & 1 & \\
\hline Financial outcomes (18) & 5.18 & 1.04 & $.32 * *$ & $.20 * *$ & $.24 * *$ & $.18 * *$ & $.28 * *$ & $.17 * *$ & $-.15 * *$ & $.16 * *$ & $.15^{*}$ & $.13 *$ & $.34 * *$ & $.30 * *$ & $.26 * *$ & .10 & $.22 * *$ & .09 & $.13 *$ & 1 \\
\hline
\end{tabular}

Financial outcomes (18)

5.18

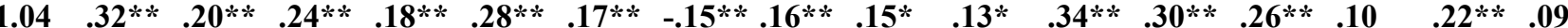

**. Correlation is significant at the 0.01 level

*. Correlation is significant at the 0.01 level 


\begin{tabular}{|c|c|c|c|c|c|c|c|c|c|c|c|c|}
\hline Construct & Indicator (number of itemsa) & Mean & $\begin{array}{l}\text { Standard } \\
\text { Deviation }\end{array}$ & $\begin{array}{l}\text { Cronbac } \\
\text { h Alpha } \\
\text { b }\end{array}$ & $\begin{array}{l}\text { Item-total } \\
\text { correlation }\end{array}$ & $\begin{array}{l}\text { Standardiz } \\
\text { ed factor } \\
\text { n loading }\end{array}$ & $\begin{array}{l}\text { Composite } \\
\text { Reliability c }\end{array}$ & $\begin{array}{l}\text { Average } \\
\text { Variance } \\
\text { Extracted d }\end{array}$ & $\begin{array}{l}\text { Squared } \\
\text { correlation }\end{array}$ & $\begin{array}{l}\text { Cronbach } \\
\text { Alpha b }\end{array}$ & $\begin{array}{l}\text { Composite } \\
\text { Reliability c }\end{array}$ & $\begin{array}{l}\text { Average } \\
\text { Variance } \\
\text { Extracted } \\
\text { c d }\end{array}$ \\
\hline \multirow{6}{*}{$\begin{array}{l}\text { Key Account } \\
\text { Management } \\
\text { Orientation }\end{array}$} & Customer orientation (5) & 5.42 & 1.05 & 0.83 & $.41-.76$ & $.56-.87$ & 0.84 & 0.52 & $.012-.446$ & 0.91 & 0.92 & 0.57 \\
\hline & $\begin{array}{l}\text { Top-management commitment } \\
\text { (5) }\end{array}$ & 5.46 & 0.99 & 0.90 & $.71-.82$ & $.81-.89$ & 0.92 & 0.64 & $.012-.465$ & & & \\
\hline & Inter-functional coordination (4) & 5.14 & 1.11 & 0.89 & $.70-.78$ & $.83-.89$ & 0.90 & 0.66 & $.028-.492$ & & & \\
\hline & Ability to customization (6) & 5.40 & 0.79 & 0.75 & $.45-.57$ & $.65-.77$ & 0.76 & 0.51 & $.024-.416$ & & & \\
\hline & top-management involvement (5) & 5.36 & 0.87 & 0.84 & $.58-.71$ & $.73-.83$ & 0.87 & 0.52 & $.017-.465$ & & & \\
\hline & Inter-functional support (3) & 5.16 & 1.06 & 0.79 & $.56-.69$ & $.79-.87$ & 0.81 & $\mathbf{0 . 5 7}$ & $.030-.492$ & & & \\
\hline \multirow{2}{*}{$\begin{array}{l}\text { Organisation } \\
\text { al Structure }\end{array}$} & Centralization (5) & 4,00 & 1,49 & 0.87 & $.67-.79$ & $.81-.89$ & 0.90 & 0.64 & $.012-.104$ & & & \\
\hline & Formalization (7) & 4,59 & 1,19 & 0.82 & $.61-.72$ & $.78-.86$ & 0.82 & 0.54 & $.012-.190$ & & & \\
\hline \multirow{2}{*}{$\begin{array}{l}\text { Relational } \\
\text { capabilities }\end{array}$} & Information sharing (4) & 4.78 & 1.18 & 0.85 & $.67-.72$ & $.82-.86$ & 0.86 & 0.59 & $.020-.180$ & 0.71 & & \\
\hline & Conflict resolution (4) & 5.32 & 0.95 & 0.75 & $.48-.60$ & $.69-.80$ & 0.76 & 0.52 & $.019-.430$ & & & \\
\hline \multirow{3}{*}{$\begin{array}{l}\text { Relationship } \\
\text { quality }\end{array}$} & Satisfaction (4) & 5.57 & 0.77 & 0.83 & $.60-.73$ & $.81-.89$ & 0.86 & 0.63 & $.018-.506$ & $\mathbf{0 . 8 7}$ & 0.89 & 0.64 \\
\hline & Trust (5) & 5.89 & 0.73 & 0.86 & $.63-.75$ & $.77-.85$ & 0.88 & 0.54 & $.012-.506$ & & & \\
\hline & Commitment (5) & 5.28 & 0.90 & 0.88 & $.67-.81$ & $.81-.91$ & 0.92 & 0.66 & $.014-.425$ & & & \\
\hline \multirow{4}{*}{$\begin{array}{l}\text { Financial } \\
\text { outcomes }\end{array}$} & Sales (1) & 5.38 & 1.11 & & & & & & & $\mathbf{0 . 8 9}$ & 0.92 & 0.68 \\
\hline & Profitability (1) & 5.12 & 1.27 & & & & & & & & & \\
\hline & Market share (1) & 5.16 & 1.18 & & & & & & & & & \\
\hline & ROI (1) & 5.05 & 1.19 & & & & & & & & & \\
\hline \multirow{4}{*}{$\begin{array}{l}\text { Non-financial } \\
\text { outcomes }\end{array}$} & I Reference value (4) & 5.92 & 0.92 & 0.87 & $.62-.80$ & $.76-.90$ & 0.91 & 0.67 & $.020-.321$ & 0.81 & $\mathbf{0 . 8 3}$ & 0.54 \\
\hline & Know-how development (4) & 5.76 & 0.96 & 0.89 & $.64-.83$ & $.78-.92$ & 0.92 & 0.69 & $.012-.321$ & & & \\
\hline & Processes' Efficiency (3) & 5.13 & 1.07 & 0.84 & $.66-.73$ & $.84-.89$ & 0.87 & 0.64 & $.028-.512$ & & & \\
\hline & Internal communication (4) & 4.47 & 1.23 & 0.95 & $.82-.91$ & $.90-.95$ & 0.96 & 0.81 & $.016-.512$ & & & \\
\hline
\end{tabular}


a Items with item-total correlations less than .30 and factor loadings less than .50 have been omitted b Reports coefficient alpha (if more than one item)

c Reports composite reliability (if more than two items)

d Average Variance Extracted is reported when there are more than two items 
Table 3: Analysis of competing structural models

\begin{tabular}{lll}
\hline Global Fit Indices & Proposed Model & Rival Model \\
\hline$\chi 2 / \mathrm{df}$ & $468.92 / 244(1.92)$ & $376.22 / 164(2.29)$ \\
$\mathrm{p}$ & $<.01$ & $<.01$ \\
$\mathrm{CFI}$ & .94 & .94 \\
NNFI & .96 & .95 \\
RMSEA & .06 & .08 \\
$\mathrm{R}^{2}$ & .48 & .44 \\
\hline
\end{tabular}


Table 4: Hypotheses Testing

\begin{tabular}{lcccl}
\hline Structural path & Hypotheses & Stnd. b & t- value & \\
\hline $\mathrm{KAMO} \longrightarrow$ Centralization & $\mathrm{H}_{\mathrm{a}}$ & $-.15^{* *}$ & $-2.64^{*}$ & Supported \\
$\mathrm{KAMO} \longrightarrow$ Formalization & $\mathrm{H}_{1 \mathrm{~b}}$ & $.23^{* *}$ & $4.09^{*}$ & Not supported \\
$\mathrm{KAMO} \longrightarrow$ Information sharing & $\mathrm{H}_{2 \mathrm{a}}$ & $.29^{* *}$ & $5.28^{*}$ & Supported \\
$\mathrm{KAMO} \longrightarrow$ Conflict resolution & $\mathrm{H}_{2 \mathrm{~b}}$ & $.47^{* *}$ & $9.31^{*}$ & Supported \\
Centralization $\longrightarrow$ Information sharing & $\mathrm{H}_{3 \mathrm{aC}}$ & -.02 & -.32 & Not supported \\
Formalization $\longrightarrow$ Information sharing & $\mathrm{H}_{3 \mathrm{aF}}$ & $.20^{* *}$ & $3.63^{*}$ & Not supported \\
Centralization $\longrightarrow$ Conflict resolution & $\mathrm{H}_{3 \mathrm{bC}}$ & $-.16^{* *}$ & $-2.80^{*}$ & Supported \\
Formalization $\longrightarrow$ Conflict resolution & $\mathrm{H}_{3 \mathrm{bF}}$ & .09 & 1.57 & Not supported \\
Centralization $\longrightarrow$ Relationship Quality & $\mathrm{H}_{4 \mathrm{aC}}$ & $-.27^{* *}$ & $-4.59^{*}$ & Supported \\
Formalization $\longrightarrow$ Relationship Quality & $\mathrm{H}_{4 \mathrm{aF}}$ & $.26^{* *}$ & $4.56^{*}$ & Not supported \\
Information sharing $\longrightarrow$ Relationship Quality & $\mathrm{H}_{4 \mathrm{bI}}$ & $.19^{* *}$ & $3.99^{*}$ & Supported \\
Conflict resolution $\longrightarrow$ Relationship Quality & $\mathrm{H}_{4 \mathrm{bCR}}$ & $.52^{* *}$ & $10.94^{*}$ & Supported \\
Relationship Quality $\longrightarrow$ Financial Outcomes & $\mathrm{H}_{5}$ & $.34^{*}$ & $6.27^{*}$ & Supported \\
Relationship Quality $\rightarrow$ Non-Financial Outcomes & $\mathrm{H}_{6}$ & $.41^{* *}$ & $7.83^{*}$ & Supported \\
$x^{2}=468.92, d f=244, \mathrm{p}<.01, \chi 2 / d f=1.92$, CFI=0.94, NNFI=0.96, RMSEA=0.06 & &
\end{tabular}

\begin{tabular}{|c|c|c|}
\hline & High span of control & Low span of control \\
\hline Method & Standardized & Standardized \\
\hline ENTER & Beta & Beta \\
\hline \multicolumn{3}{|l|}{ Financial outcomes } \\
\hline Relationship quality & $0.34^{*}$ & $0.36^{*}$ \\
\hline Adjusted R Square & 0.16 & 0.17 \\
\hline
\end{tabular}


Chow Test

Non-financial performance

Relationship quality

$0.40 *$

$0.42 *$

Adjusted R Square

0.34

0.36

Chow Test

$\mathrm{F}: 6.72 *$

Relationship quality

Centralization

$-0,29 *$

$-0.27 *$

Formalization

$0.26^{*}$

$0.26^{*}$

Adjusted R Square

0,18

0,19

\begin{tabular}{lcc}
\hline Chow Test & F: $4.62^{*}$ & \\
\hline Information sharing & $0.18^{*}$ & $0.19^{*}$ \\
Conflict resolution & $0.51^{*}$ & $0.52^{*}$ \\
Adjusted R Square & 0,28 & 0,29
\end{tabular}

Chow Test

F: 5.14*

*p $<0,001$

Figure 1: Conceptual model

Organisational Structure

Performance Outcomes

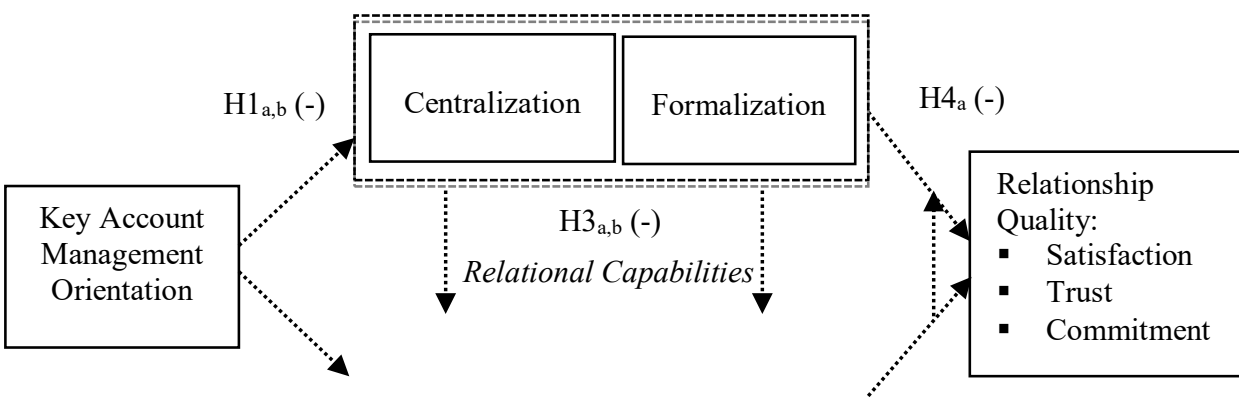

\begin{tabular}{|c|c|}
\hline $\mathrm{H} 5($ & $\begin{array}{l}\text { Financial outcomes: } \\
\text { - Sales } \\
\text { - Profitability } \\
\text { - } \text { Market Share } \\
\text { - } \text { ROI } \\
\end{array}$ \\
\hline & $\begin{array}{l}\text { Non-Financial outcomes: } \\
\text { - } \quad \text { Reference value } \\
\text { - Know-how development } \\
\text { - Processes' efficiency } \\
\text { - Internal communication }\end{array}$ \\
\hline
\end{tabular}



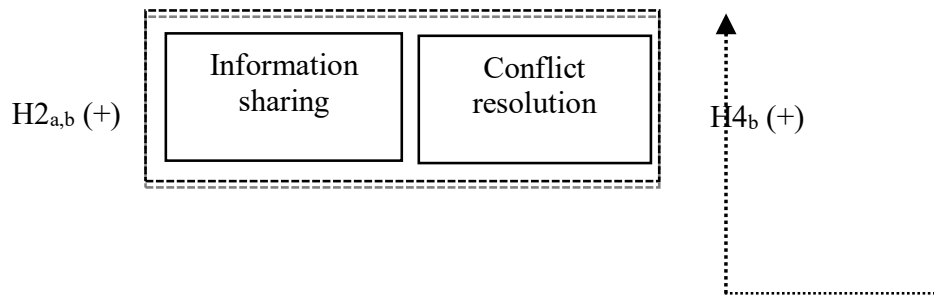

H6 (+)

H7 (-)

Control variable Span of control

Figure 2: Rival model

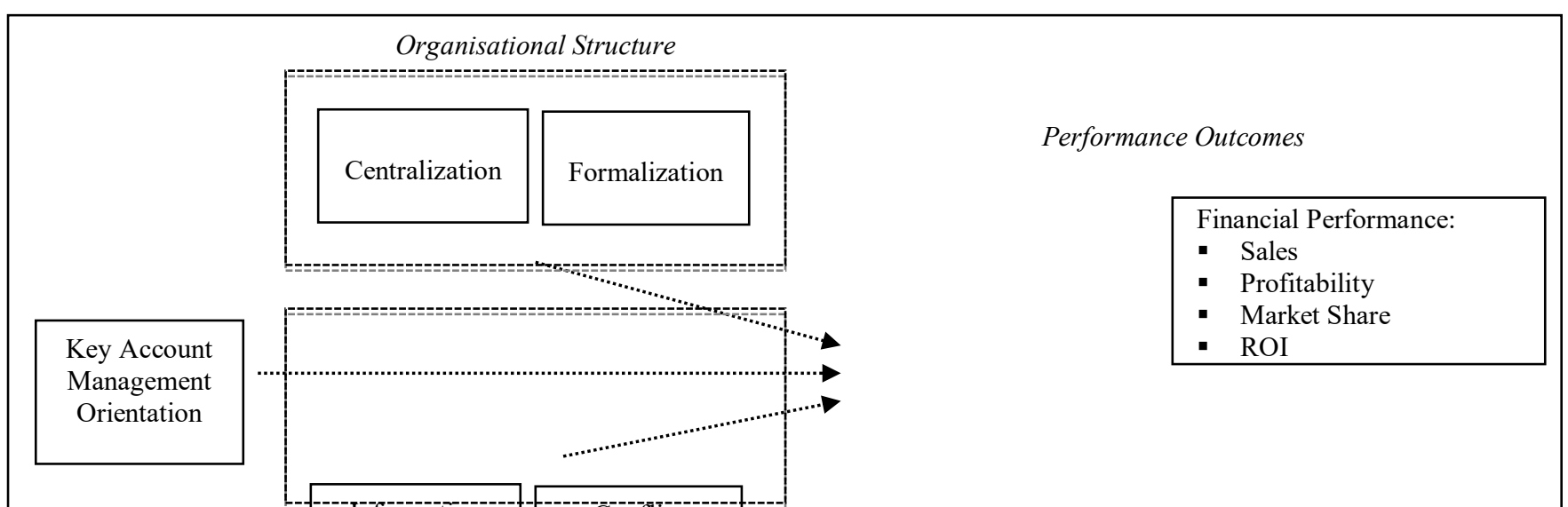




$$
\begin{aligned}
& \text { Relationship } \\
& \text { Quality: } \\
& \text { - Satisfaction } \\
& \text { - Trust } \\
& \text { - Commitment }
\end{aligned}
$$

Non-Financial Outcomes:

- Reference value

- Know-how development

- Processes' efficiency

- Internal communication 